\title{
Assessing Future Changes of Climate Extreme Events in the CORDEX-MENA Region Using Regional Climate Model ALADIN-Climate
}

\author{
Fatima Driouech $^{1}$ (I) $\cdot$ Khalid EIRhaz $^{2} \cdot$ Willfran Moufouma-Okia $^{3} \cdot$ Khadija Arjdal $^{1} \cdot$ Saloua Balhane $^{1}$
}

Received: 6 January 2020 / Accepted: 28 July 2020 / Published online: 25 August 2020

(c) The Author(s) 2020

\begin{abstract}
This study investigates future changes of temperature, precipitation, and associated extreme events in the MENA region using Regional Climate Model ALADIN-Climate over the CORDEX-MENA domain. Model capabilities to reproduce key observed regional climate features are first assessed, including heat waves, drought and high precipitation extremes. Projected changes indicate the intensification of heat waves number, duration and magnitude, and contrasted precipitation changes. A drying is projected in the north-west and moistening in the north-east along the Mediterranean side of the region. Projected regional warming is found at the rate of about $0.2{ }^{\circ} \mathrm{C} / \mathrm{decade}$ to $0.5{ }^{\circ} \mathrm{C} / \mathrm{dec}$ ade over land depending on the scenario. Drought is expected to increase in the northern half of the region independently from the index used, but with a higher rate in the case of the index accounting for both the effect of precipitation and temperature changes. ALADIN-Climate results corroborate previous studies projecting the MENA region to host global hot spots for drought in the late twenty-first century.
\end{abstract}

Keywords Extremes $\cdot$ Regional climate change $\cdot$ CORDEX $\cdot$ MENA $\cdot$ Heat waves $\cdot$ Drought

\section{Introduction}

The Middle East and North Africa (MENA) region extends from the Maghreb in Northwest Africa to the Arabian Peninsula. The MENA region has been proned to climate hazards (Lelieveld et al. 2016; Waha et al. 2017). These include the devastating Syrian Arab Republic's droughts in 1998-2000 and 2007-2010 (Kelley et al. 2015; Flohr et al. 2017), the recurrent droughts registered during 1980-1994 in Morocco (Mansouri 2004; Driouech 2010), the prolonged drought of Greater Horn of Africa (Shongwe et al. 2011; Mwangi et al. 2014; Rowell et al. 2015; Gebremeskel et al. 2019), drought registered in Jordan and Lebanon in 2014 (Dai 2011; Barlow et al. 2016), as well as important changes of climate characteristics are evidenced by several studies focusing on climate trends at regional and local scales (Nasrallah et al. 2004;

Fatima Driouech

Fatima.driouech@um6p.ma

1 University Mohamed VI Polytechnique, Benguerir, Morocco

2 Direction Générale de la Météorologie, Casablanca, Morocco

3 Regional Climate Prediction Services Division, World Meteorological Organization, Geneva, Switzerland
Zhang et al. 2005; Driouech 2010; AlSarmi and Washington 2011; Dahech and Beltrando 2012; Almazroui et al. 2014; Donat et al. 2014; Filahi et al. 2015; Almazroui 2019a).

The high climate vulnerability of this region is widely recognized and several negative impacts are expected to make the strengthening of resilience and adaptation (Sowers et al. 2011; United Nations Economic and Social Commission for Western Asia (ESCWA) et al. 2017; Waha et al. 2017). Significant and consistent warming trends have been depicted since the middle of the twentieth century across the region with increased frequencies of warm days and warm nights, fewer cold days and cold nights and higher extreme temperature values (Tramblay et al. 2013; Donat et al. 2014; Islam et al. 2015; Merlone et al. 2019; Almazroui 2020). Although less regionally consistent, downward trends of total precipitation amounts have been found in different sub-regions of MENA jointly with an increase in drought (Tanarhte et al. 2012; Driouech et al. 2013; Tramblay et al. 2013; Donat et al. 2014).

Recent scientific and technical advances have explored the issue of the habitability of the Earth under increasing anthropic pressure using General Circulation Models (GCMs), Regional Climate Models (RCMs) and other climate downscaling techniques (IPCC 2018; Déqué et al. 
Fig. 1 Domain covered by ALADIN-Climate simulations. The active region where the RCM results are used (yellow) includes the CORDEX-MENA domain (blue); the Intermediate zone (green) indicates the relaxation area for the coupling; the Extension zone (red) is the area for bi-periodization. The full domain (red + green + yellow zones) indicates the area needed for the RCM to perform properly. The area between active and full domain is a transition zone between the GCM driving boundaries and the RCM

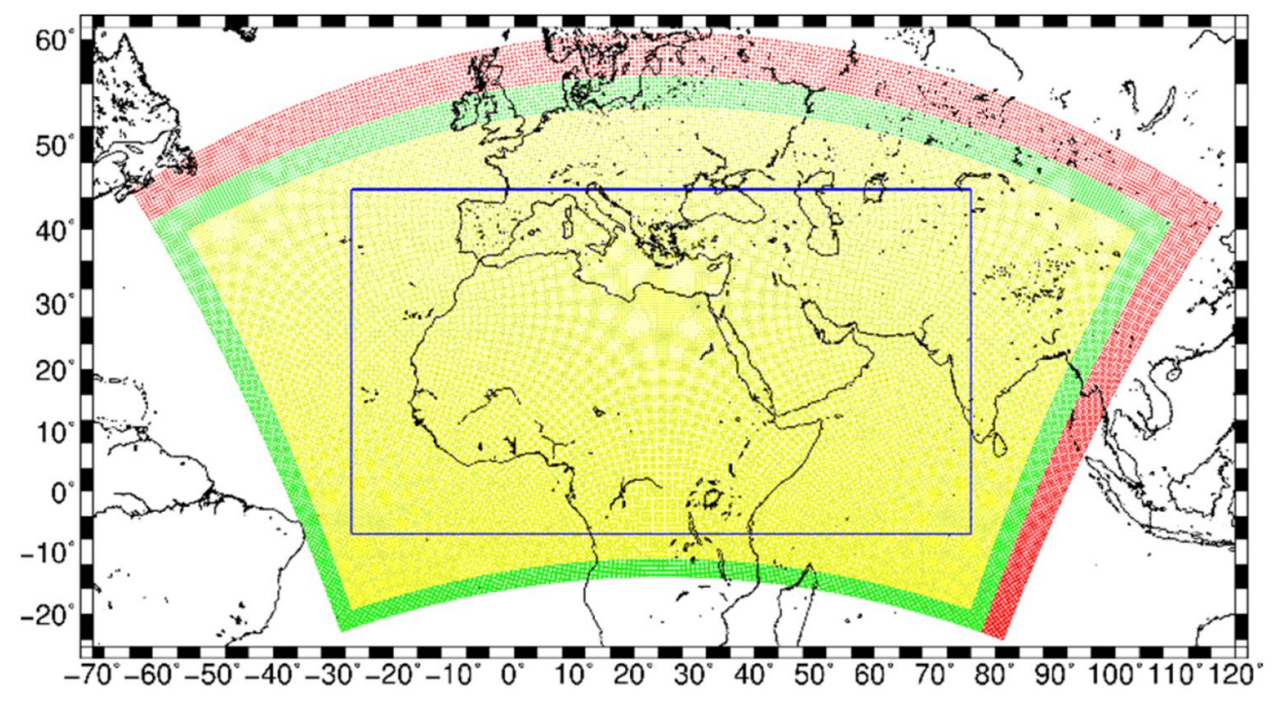

2017; Field et al. 2012). GCMs are the principal tools for investigating the large-scale response of the climate system to various forcings, for making climate predictions on seasonal to decadal time scales and for making projections of future climate over the coming century and beyond (Flato et al. 2013). For example, Almazroui et al. (2020) demonstrated the changes in temperature and precipitation using latest Coupled Model Intercomparison Project (CMIP6) simulations for Africa under the three Shared Socioeconomic Pathways (SSPs). They found that future warning is not uniform over Africa and varies regionally, which demand the necessity of downscaling GCM dataset using RCM. However, GCMs are not suitable for studying extreme phenomena over a region like MENA where climate fluctuations are subject to enhanced spatial heterogeneity, due to their coarse spatial resolution. RCMs and other climate downscaling techniques have been used for "zooming in" the results of the GCMs on a particular area of the globe. Also, RCMs provide fine-scale resolution and improved physical formulation for mesoscale processes, and the ability to account for local-scale physiographic drivers of regional climate features (Giorgi and Lionello 2008; Rummukainen 2010; Giorgi and Gutowski 2015; Gutowski et al. 2016; Lennard et al. 2018). But, it rapidly appeared that climate change responses from RCM depend both on the emission scenarios, large-scale driving fields from the global model, and the RCM physical formulation (Hernández-Díaz et al. 2013; Laprise et al. 2013; Llopart et al. 2014; Dosio et al. 2015; Almazroui et al. 2016).

The Coordinated Regional Climate Downscaling Experiment (CORDEX) of the World Climate Research Programme provides a novel and standardized approach to assess RCM climate change responses over predefined geographic domains worldwide (Jacob et al. 2014; Giorgi et al. 2014; Llopart et al. 2014; Roudier et al. 2015; Gutowski et al. 2016; Zou and Zhou 2016; Lennard et al. 2018; Mba et al. 2018). The CORDEX program aims at enhancing international cooperation and improving the understanding of relevant regional/local climate phenomena, their variability and changes. Considering the need for a common climate downscaling framework to evaluate future changes and impacts in the MENA region, the CORDEX "Region 13: Middle East North Africa (MENA)" regional domain (CORDEXMENA) has been established recently under CORDEX. This domain, illustrated in Fig. 1, was initially defined within the framework of the Regional Initiative for the assessment of Climate Change impacts on water resources and socioeconomic vulnerability in the Arab Region (RICCAR; https ://www.escwa.un.org/RICCAR) jointly established by the Arab League and the United Nations Economic and Social Commission for Western Asia (ESCWA). However, much of the CORDEX research in the MENA region has focused on evaluating the RCMs to reproduce historical climate features, with models forced either by large-scale atmospheric conditions from reanalyzes or GCMs. Furthermore, and despite the numerous similarities the region presents, very few climate assessment studies have been performed for the whole region.

The MENA climate is predominantly semi-arid to arid with generally dry and hot summers and mild winters (Donat et al. 2014), and is controlled by oceanic forcing related to heat, humidity and winds coming from surrounding oceans (Almazroui 2019b). The annual total precipitation exhibits significant spatial and temporal variability, and most land areas receive less than $300 \mathrm{~mm}$ of annual precipitation (Waha et al. 2017). Over the Arabian Peninsula, spatial variability of precipitation is high, due to the Mediterranean climate's, Indian monsoon and orographic variations (Bucchignani et al. 2015). Precipitation exceeds $900 \mathrm{~mm}$ in temperate zones, such as the Atlas Mountains in Morocco, the 
western part of Jordan, Syrian Arab Republic and Lebanon and Palestine (United Nations Economic and Social Commission for Western Asia (ESCWA) et al. 2017). Annual mean temperature range from less than $10^{\circ} \mathrm{C}$ to more than $30{ }^{\circ} \mathrm{C}$ with the highest values located over the desert lands, characterized by very high daily fluctuations and hot summers (reaching $40{ }^{\circ} \mathrm{C}$ to more than $50{ }^{\circ} \mathrm{C}$ ). The temperature is moderated by elevation and by proximity to the sea. The southern part of the region, including southern Mauritania and southern Sudan, benefits from wet tropical climate and receives about $100-600 \mathrm{~mm} /$ year with a mean annual temperature of about $18{ }^{\circ} \mathrm{C}$ (United Nations Economic and Social Commission for Western Asia (ESCWA) et al. 2017).

In this study, we assess for the first time the climate change responses of the ALADIN-Climate ("Aire Limitée Adaptation dynamique Développement InterNational") RCM over the CORDEX-MENA domain, with a focus on changes of temperature and precipitation extremes. The main objective is to contribute to the improved understanding of future climate extremes in this region. The article is organized as follows. Section 1 describes the key model formulation features and assessment metrics. Section 2 provides a brief evaluation of the model performance in simulating climatological characteristics over the MENA region. Future changes are assessed in Sect. 3 and a conclusion is presented in Sect. 4.

\section{Data and Methods}

\subsection{Model and Experimental Design}

This study uses version 5 of the limited-area Regional climate Model ALADIN-Climate (Déqué and Somot 2008; Radu et al. 2008; Colin et al. 2010; Farda et al. 2010; Herrmann et al. 2011; Nabat et al. 2014; Ruti et al. 2016; Mallet et al. 2019; Spiridonov and Valcheva 2019) with a horizontal resolution of $50 \mathrm{~km}$. The model physical formulation is inherited from ARPEGE-Climat and CNRM-CM5 CGCMs used in the Coupled Model Intercomparison campaigns (Déqué 2010; Voldoire et al. 2013). The dynamical core is bi-spectral with semi-implicit, semi-lagrangian advection scheme, and includes an 11-point wide bi-periodization zone in addition to the more classical 8-point relaxation zone. ALADIN-Climate comprises the Fouquart and Morcrette radiation scheme based on the European Centre for Medium Range Forecasts (ECMWF) model, incorporating effects of greenhouse gases $\left(\mathrm{CO}_{2}, \mathrm{CH}_{4}, \mathrm{~N}_{2} \mathrm{O}\right.$ and $\left.\mathrm{CFC}\right)$ and direct effects of aerosols, as well as the first indirect effect of sulphate aerosols. The vertical discretization has 31 layers, with 27 layers from the surface up to the tropopause and a time step of $15 \mathrm{~min}$.
Version 5 of ALADIN-Climate is used in this work, as was the case within the framework of MedCORDEX (Torma et al. 2015; Ruti et al. 2016; Somot et al. 2018; Vaittinada et al. 2016; Fantini et al. 2018). Three simulations have been carried out by the RCM with a horizontal resolution of $50 \mathrm{~km}\left(\sim 0.44^{\circ}\right)$ driven by lateral boundary conditions from the CMIP5 Global Climate CNRM-CM5 (Salas-Mélia et al. 2005; Voldoire et al. 2013) over the domain shown in Fig. 1. This domain includes the active part (yellow area) where the RCM results are considered usable and the transition zone between the GCM driving boundaries and the RCM (red and green zones). The area considered for analysis (blue rectangle) coincides with the CORDEX-MENA domain. The historical simulation covers the period 1971-2005 and uses observed aerosol field and Greenhouse gas (GHG) concentrations (Tramblay et al. 2013; Farda et al. 2010). Two other simulations were run over the period $2006-2100$ based on the Representative Concentration Pathways RCP4.5 and RCP8.5, respectively.

Note that Version 4 of ALADIN-Climate was used for the European ENSEMBLES project where it was inter-compared with several European RCMs at 50-km and $25-\mathrm{km}$ resolution, and was also used for the assessment of future climate change over Morocco (Driouech 2010; Driouech et al. 2010).

\subsection{Climate Indices}

Model capabilities and future climate changes over the region are assessed using a set of sector-specific climate indices derived from daily temperature and precipitation data, and designated to assess simple and complex climate risks (https://climpact-sci.org/indices/) in socio-economic sectors such as water resources, agriculture and health. These indices form the standardized set recommended by the World Meteorological Organization (WMO) Commission of Climatology Expert Team on Sector-Specific Climate Indices (ET-SCI), ${ }^{1}$ parts of which is based on those defined by the joint Expert Team on Climate Change Detection and Indices (ETCCDI) ${ }^{2}$ (Peterson 2005; Zhang et al. 2011; Alexander and Herold 2016). Furthermore, to the annual mean temperature and the total precipitation from wet days, we selected indices relative to extreme temperature and precipitation including heat waves, high precipitation events and drought. These indices were determined by the ET-SCI in

\footnotetext{
${ }^{1}$ https://www.wmo.int/pages/prog/wcp/ccl/ccl17/focusarea/fa3/CCl17FA3ET-SCIWMO.php

2 The joint World Meteorological Organization (WMO) Commission for Climatology $(\mathrm{CCl})$, Climate Variability and Predictability (CLIVAR), and Joint Technical Commission for Oceanography and Marine Meteorology (JCOMM) Expert Team on Climate Change Detection and Indices.
} 
consultation with sector representatives of Health, Agriculture and Food Security and Water Resources and Hydrology depending on the index (Perkins and Alexander 2013). All indices used in the remaining of this paper are calculated at the annual time scale:

o Annual mean temperature (in ${ }^{\circ} \mathrm{C}$ ). Daily mean temperature (TM) consisting in the half-sum of daily maximum (TX) and minimum (TN) temperatures.

o Total consecutive hot days and hot nights defined as the annual count of $n$ consecutive days where both TX $>$ 95th percentile (i.e., Fraction of days with hot day time temperatures) and TN $>95$ th percentile (i.e., Fraction of days with warm night time temperatures), where $n=3$ (TX3TN3, in days).

o The number of individual heat waves (HWN, in number of events) consisting of the number of individual heat waves that occur each summer (May-Sep). A heat wave is defined as 3 or more days where the Excess Heat Factor (EHF) is positive (Perkins and Alexander 2013). The EHF is a combination of two Excess Heat Indices (EHI) representing the acclimatization to heat (EHI(accl.)) and the climatological significance (EHI(sig.). Compared to other heat wave definitions (i.e., based on TX or TN thresholds), the EHF-based heat wave is, from a climatological standpoint, the most appealing as it considers TX and TN within the same index (Alexander and Herold 2016). In addition, the conditions leading up to a given day (i.e., the previous 2 days) are also considered. The given day is also compared to an extreme threshold (via the 90th percentile) to determine its climatological anomaly, and to the mean of the preceding month to determine the anomaly against recent conditions. The EHF is calculated as (Alexander and Herold 2016):

$$
\begin{aligned}
& \text { EHI }(\text { accl. })= {[(\mathrm{TMi}+\mathrm{TMi}-1+\mathrm{TMi}-2) / 3] } \\
&-[(\mathrm{TMi}-3+\ldots+\mathrm{TMi}-32) / 30] \\
&\text { EHI(sig. })=[(\mathrm{TMi}+\mathrm{TMi}-1+\mathrm{TMi}-2) / 3]-\mathrm{TM} 90 \mathrm{i}
\end{aligned}
$$

where TMi represents the average daily temperature for day i (i.e., TMi-32 is the average daily temperature for day $\mathrm{i}-32$ ) and TM90i is the 90th percentile of TM over all calendar day $i$ within the user-specified base period, using a 15-day running window. TM is calculated via $\mathrm{TM}=(\mathrm{TX}+\mathrm{TN}) / 2$.

The EHF is defined from the above two definitions: $\mathrm{EHF}=\mathrm{EHI}($ sig. $) \times \max (1, \mathrm{EHI}(\mathrm{accl}$. $))$.

o length in days of the longest heatwave identified by HWN. o Heat Wave Magnitude ( $\mathrm{HWM}$, in ${ }^{\circ} \mathrm{C}^{2}$ ) corresponding to the mean EHF of all heat waves identified by HWN. It is calculated as the mean of the mean HW days of each HW defined by HWN

o Annual total wet-day precipitation (PRCPTOT, in $\mathrm{mm}$ ) calculated as the sum of daily precipitation from wet days (days when precipitation is $>=1.0 \mathrm{~mm}$ )

o Standardized Precipitation Index (SPI, dimension less) measuring drought as a precipitation deficit after it has been fitted to a probability density function (McKee et al. 1993). This multi-scalar drought index is normally distributed, and its values correspond to the number of standard deviations from the mean. Thus, negative values indicate drought and positive indicate excessive wet. The SPI has been accepted by WMO as the reference drought index for drought monitoring and climate risk management (World Meteorological Organization 2012).

o Standardized Precipitation-Evapotranspiration Index (SPEI, dimension less), a drought measure specified using precipitation and evaporation (Vicente-Serrano et al. 2010). It is a multi-scalar drought index similar to SPI with the addition of temperature to consider the effect of potential evapotranspiration (PET). Several studies have shown that temperature rise affects the severity of droughts and the role of warming-induced drought stress has been highlighted in different studies that have analyzed drought impacts (Barriopedro et al. 2011; Linares and Camarero 2012; Vicente-Serrano et al. 2014).

o Amount of rainfall from very wet days (R95p, in mm) corresponding to the annual total precipitation from heavy rain days (days $>95$ th percentile).

o Amount of rainfall from extremely wet days (R99p, in $\mathrm{mm}$ ) corresponding to the annual total precipitation from very heavy rain days (days $>99$ th percentile).

The drought index SPEI and heat wave indices based on the Excess Heat Factor have not been evaluated before over the MENA region in terms of future changes at high resolution neither in terms of observed trends.

For each index, the statistical significance tests of changes were undertaken, at a confidence level of $95 \%$, on each gridpoint. The Mann-Whitney $U$ test was used, as precipitation has a skewed distribution in many arid regions and the test makes no assumptions about the distribution (James and Washington 2013). 


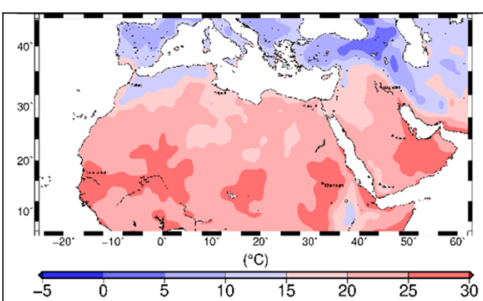

(a)

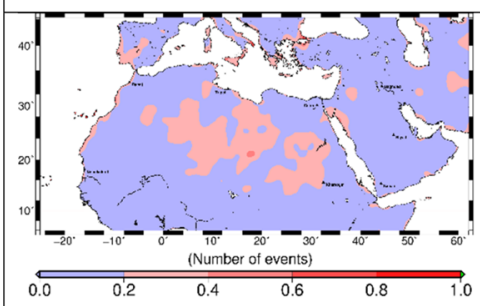

(d)

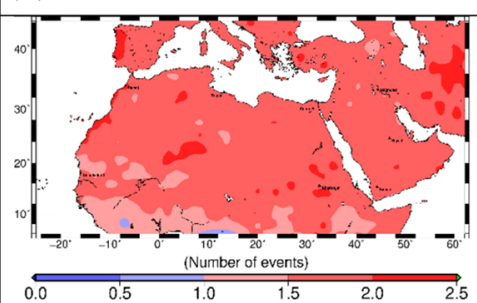

(g)

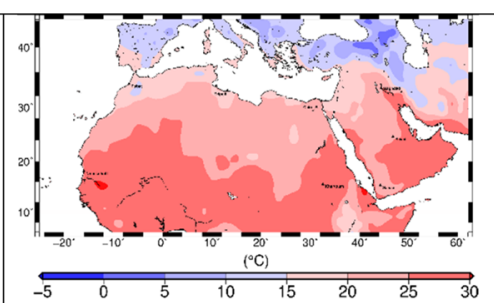

(b)

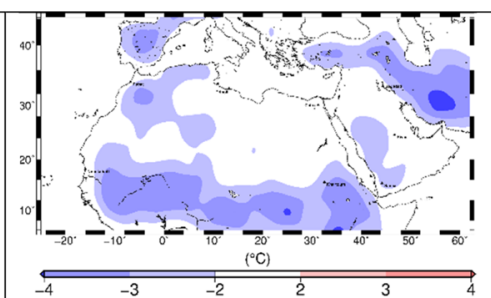

(c)

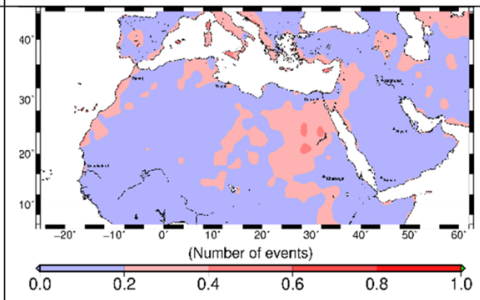

(e)

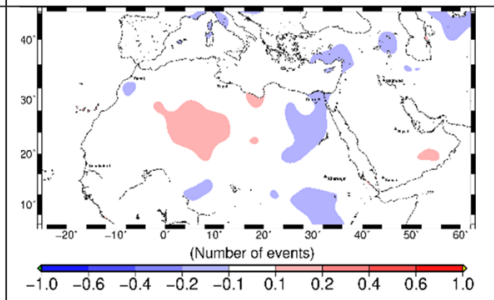

(f)

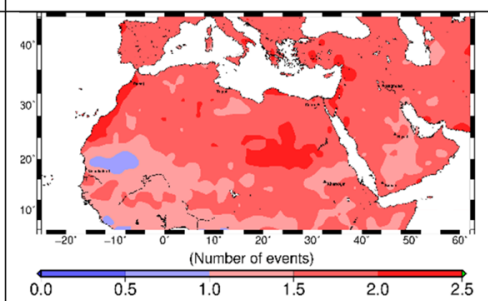

(h)

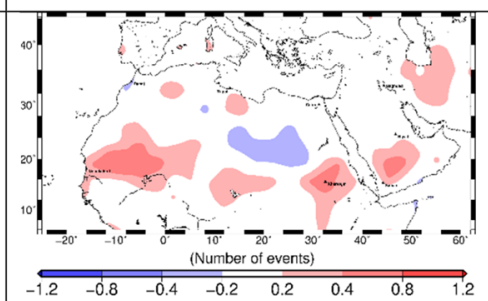

(i)
Fig. 2 Climatological mean temperature and hot extreme events simulated by ALADIN-Climate RCM (left panels) and derived from ERA5 reanalysis (middle panels) for the historical period (1979-

\section{Model Evaluation}

The climate model ability to reproduce the MENA climatic features is assessed by comparing simulated outputs against observed datasets for the historical/reference period. The evaluation of ALADIN-Climate over the MENA domain (described in Sect. 1.1) is conducted using the fifth generation of ECMWF atmospheric reanalysis of the global climate (ERA5) data, recently developed (Hersbach and Dee 2016; Hersbach et al. 2018, 2019). ERA5 data cover the Earth on a 30-km fine grid and replaces the ERA-Interim reanalysis which stopped being produced in August 2019. ERA5 improves over ERA-Interim and combines vast amounts of historical observations (including remote sensed and in situ data) into global estimates using advanced modeling and data assimilation systems. For the purpose of this study, $\mathrm{ERA} 5^{3}$ data daily maximum, minimum temperature and precipitation are interpolated onto the 50-km grid of ALADINClimate RCM. The climate indices used in the analysis are

\footnotetext{
3 (https://www.ecmwf.int/en/forecasts/datasets/reanalysis-datasets/ era5).
}

2005), and their differences (right panels). Annual mean temperature $(\mathbf{a}, \mathbf{b}, \mathbf{c})$, number of consecutive hot days and nights (TX3TN3) (d, e, f) and number of heat waves $(\mathrm{HWN})(\mathbf{g}, \mathbf{h}, \mathbf{i})$

listed in Sect. 2.2 and calculated for the historical period (1979-2005). Note that a more appropriate evaluation of the RCM requires performing simulation driven by reanalysis (representing "perfect" boundary conditions), free from biases carried over from the GCM. Uncertainties linked to gridded observational datasets may also be significant due to, for example, the density of the meteorological network (Contractor et al. 2015; Prein and Gobiet 2017; Zittis 2018).

\subsection{Mean Temperature and Hot Extreme Events}

Figure 2 compares mean temperature and hot extreme indices in model data and ERA5 reanalysis. Regional mean temperature anomalies are calculated by averaging the land grid point values within the domain. ALADIN-Climate captures key features of temperature variations and the warming trend, though there is a cold bias in different parts of the region especially over the mountainous regions (Figs. 2a, b, c and 3).

The absolute mean bias of temperature anomalies averaged over land grid point values is small and does not exceed $0.17^{\circ} \mathrm{C}$. The CNRM5 model exhibits a similar pattern of cold bias indicating that this feature is inherited from the 
Fig. 3 Annual mean temperature anomalies simulated by ALADIN-Climate RCM (green curve) and derived from ERA5 reanalysis (black curve) for the historical period (1979-2005). Future changes issued from the RCM according to the Representative Concentration Pathways scenarios RCP4.5 (blue) and RCP8.5 (red)

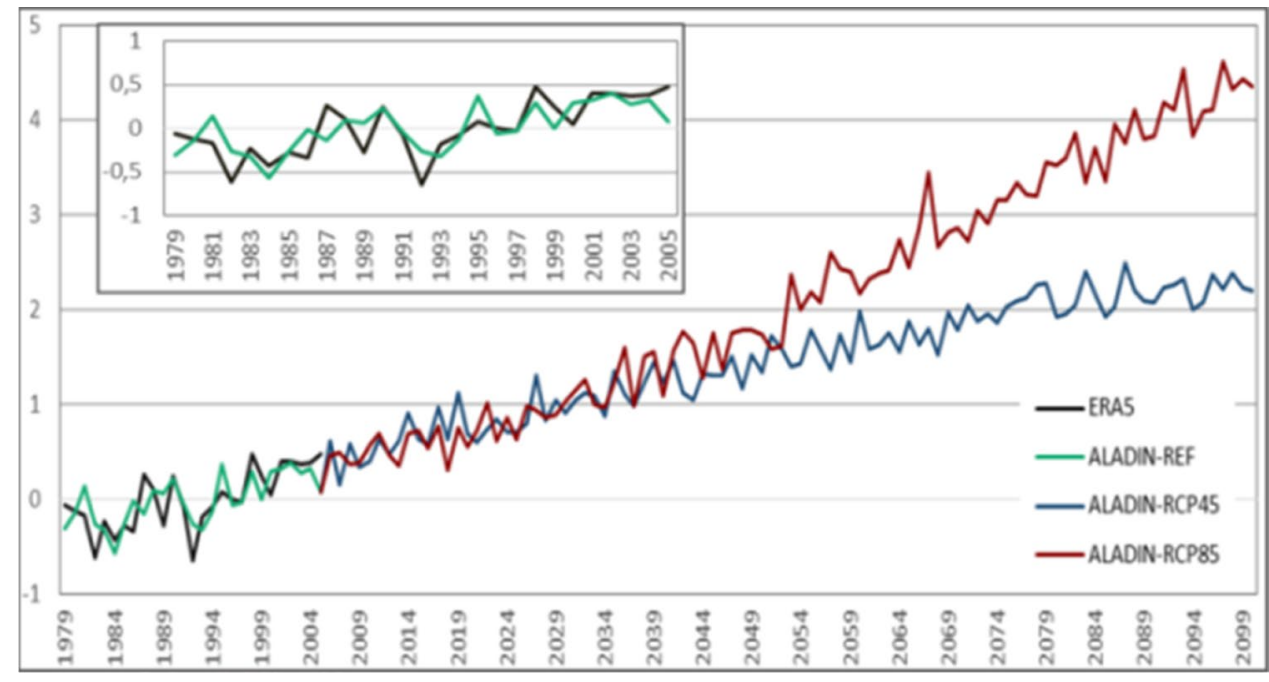

driving GCM (Voldoire et al. 2013; Dosio et al. 2015). Temperature biases have been attributed to systematic errors in non-dynamical processes, while the main features of the large-scale dynamics are well captured in such experiments driven by observed sea-surface temperatures (Cattiaux et al. 2013). Note that CNRM5 is an improved physical formulation of the CNRM3 GCM which also exhibited large cold bias (Voldoire et al. 2013). Cold biases linked to the driving GCMs are also found in simulations undertaken within RICCAR initiative over CORDEX-MENA domain using three different RCMs. (United Nations Economic and Social Commission for Western Asia et al. 2017). RCM outputs have been compared with ERA-Interim Reanalysis over the 25-year period 1980-2004. Other studies have also highlighted cold biases of climate models over the region (Syed et al. 2019; Dike et al. 2015; Ozturk et al. 2018; Zittis et al. 2014). Temperature biases are even higher in some parts of the region although some model simulations were integrated under 'quasi perfect boundary' conditions (driven by reanalysis). Cold biases have been also found in both minimum and maximum temperatures (Zittis et al. 2014), the setup for cloud microphysics seems to have the strongest impact on such biases.

In terms of hot extremes, results show that events with three consecutive hot days and nights (TX3TN3) occur in ERA5 data with a frequency mostly not exceeding 1 time per each 2 years. This means that, hopefully, most of the extreme hot events involving both extreme high maximum and minimum temperatures do not persist generally more than 1 or 2 days in the region. Simulating such kind of events and their evolutions is, however, very useful in the context of global warming due to the damages they can engender and the need for adaptation. For example, the capability for relief and adaptation can have a profound impact on excess mortality and morbidity (Meehl and Tebaldi 2004; Hansen et al. 2008, Ahmadalipour and Moradkhani 2018; Ahmadalipour et al. 2019). These "relatively" low values of TX3TN3 are well reproduced over the entire region exhibiting the model ability to simulate the temporal persistence of hot extreme events (Fig. 2d, e, f). This is further demonstrated by the simulated magnitude of the extended summer (May-September) heat waves (HWM) (not shown), except over the Atlantic coastal zones of Morocco where the HWM reaches its maximum probably due to a high climatological significance (EHI(sig.)) of heat waves (see Sect. 1.2 for calculation of HW). These coastal zones register generally high temperature values during heat waves compared to its 90th percentile which gives a higher EHF (sig.) than in inland zones.

ALADIN-Climate also captures well the numbers of heat waves (HWN) with an absolute mean bias not exceeding 0.4 in approximately all the domain (Fig. $2 \mathrm{~g}, \mathrm{~h}, \mathrm{i}$ ). The length of the longest heat wave (HWD) modeled is as well satisfactory compared with reanalysis despite some overestimation in parts of Saudi Arabia and Egypt and underestimations along the African monsoon regions south of the domain (not shown). However, the biases do not exceed 2 days in nearly all the domain.

\subsection{Mean Precipitation and High Precipitation Events}

ALADIN-Climate reproduces the spatial distribution of annual mean precipitation across the domain and captures the main features including the lowest precipitation amounts in the dry African Sahara and Arabian Desert (precipitation less than $1 \mathrm{~mm} \mathrm{day}^{-1}$ ), the rainfall enhancement over complex terrains (such as Zagros Mountains and the Yemen mountains), as well as the precipitation band in the south associated with the Inter-Tropical Convergence Zone (ITCZ) over Africa (Fig. 4a, b, d, g, e, h). Moreover, the humid zone of North Africa associated with the North Atlantic-Mediterranean cyclones is well represented. 


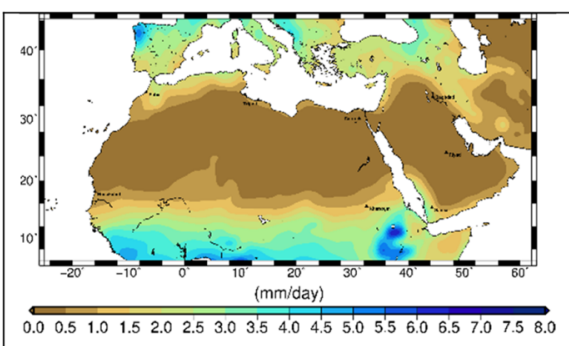

(a)

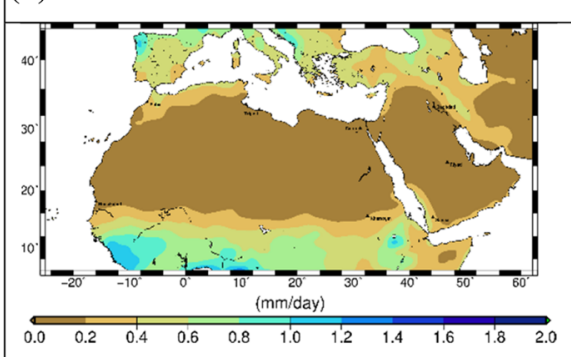

(d)

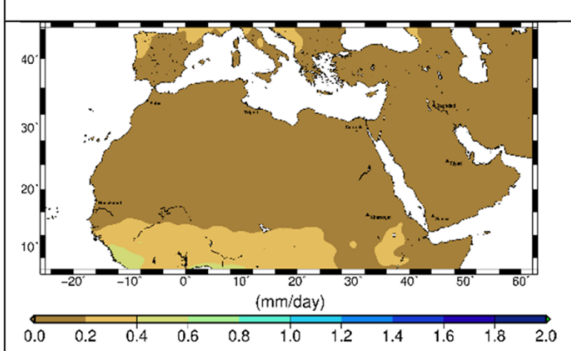

(g)

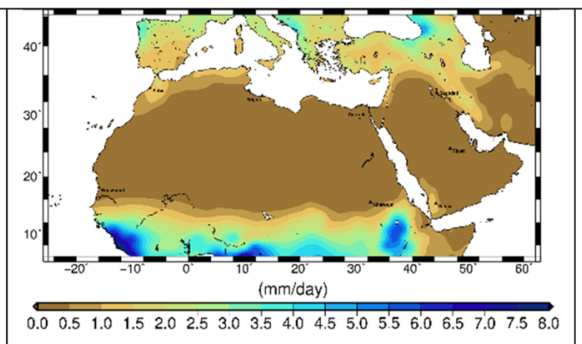

(b)

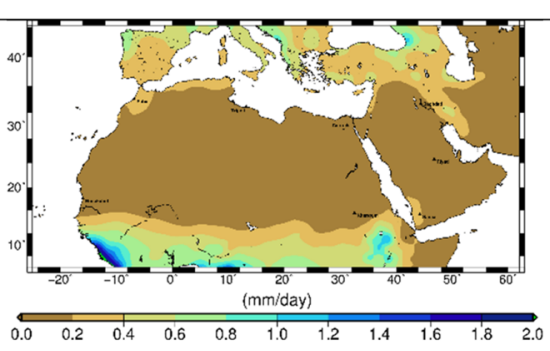

(e)

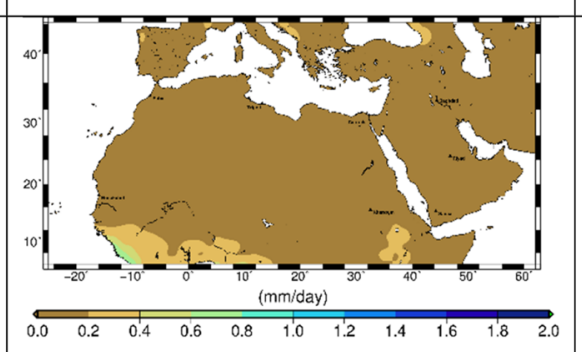

(h)

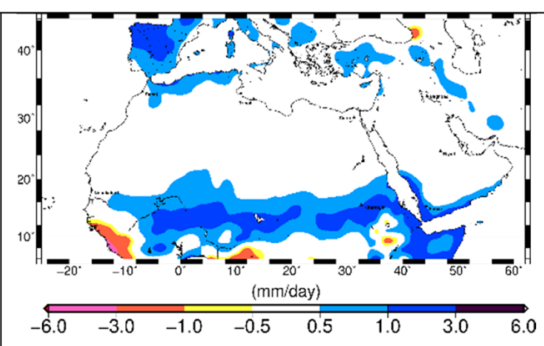

(c)

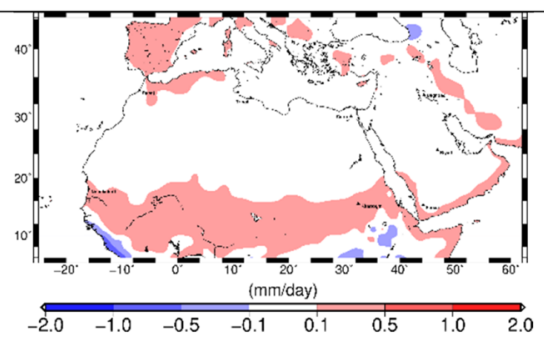

(f)

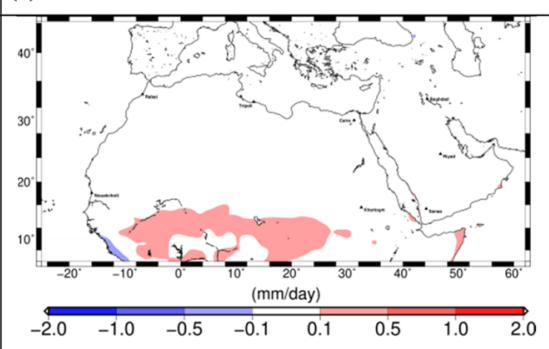

(i)
Fig. 4 Climatological annual precipitation and extreme precipitation events simulated by ALADIN-Climate RCM (left panels) and derived from ERA5 reanalysis (middle panels) for the historical period

The simulation exhibits, however, a tendency to slightly overestimate the annual total precipitation amounts over the mountainous areas and along the belt under the influence of African monsoon south of the domain (where a model cold bias is noted). A dry bias is apparent in the most humid part of tropical West Africa located southwest of the domain (Fig. 4c, f, i). Overestimation of precipitation in the MENA-Region by RCM simulations have been found by some previous studies (i.e., over the Sahara Desert (Zittis et al. 2014; Ozturk et al. 2018) while others exhibited, in the contrary, dry biases [i.e., over North Africa and Arabian Peninsula Bucchignani et al. (2015)]. The few RCM biases found here remain low in most cases consistently with the driving model (Voldoire et al. 2013) which showed improved skill in reproducing circulation patterns in retrospective simulations in Arabian Peninsula compared to a set of CMIP5 GCMs (El Kenawy and McCabe 2016). Zhao et al. (2014) found that CNRM-CM5 performs best for precipitation over North Africa among the models used.
(1979-2005) and their respective differences (right panels). Mean annual precipitation $(\mathbf{a}, \mathbf{b}, \mathbf{c})$, the total precipitation issued from very wet days $(\mathbf{d}, \mathbf{e}, \mathbf{f})$ and extremely wet days $(\mathbf{g}, \mathbf{h}, \mathbf{i})$

The spatial patterns of total precipitation due to very wet days (R95p) and extremely wet days (R99p) are also well reproduced by ALADIN-Climate. The largest intensities are found around orographic regions and in the tropical wet area resulting from deep convection occurrences (Diedhiou et al. 1998; Sylla et al. 2013;). Consistent with observations, the minima occur in the Sahara and Arabian Desert. The model overestimates the amplitudes of precipitation, although wet biases remain relatively low, over the mountainous areas and along the belt under the influence of the West African Monsoon (WAM). Overestimations of total high precipitation amounts are also found in the case of CORDEX multi-model ensembles compared to GPCP datasets (Huffman et al. 2009). Comparison of CORDEX outputs against TRMM data (Huffman et al. 2007) indicates better estimations, highlighting the potential effect of the observational dataset (Gibba et al. 2018). Several differences have also been found in the magnitudes of the two observational datasets (e.g., GPCP and TRMM), where the TRMM generating larger intensities than the GPCP. 


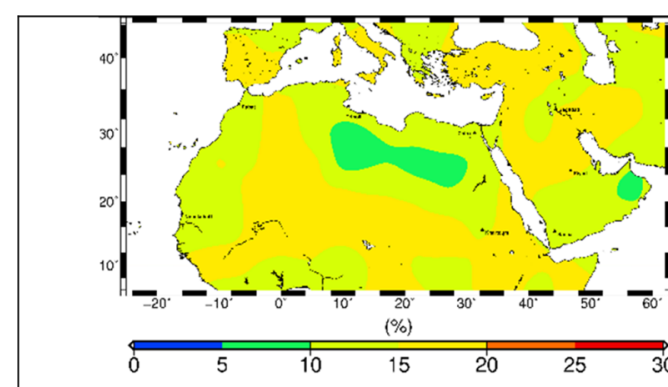

(a)

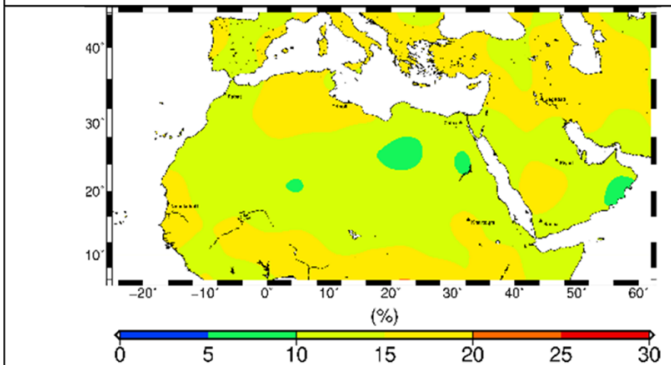

(b)

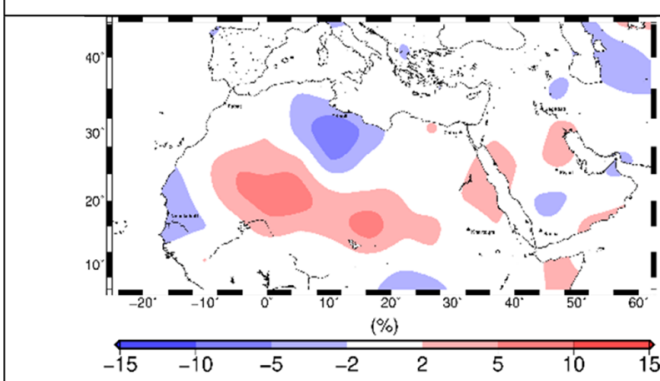

(e)

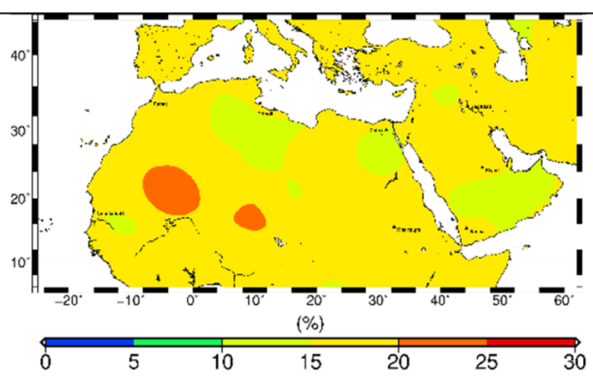

(c)

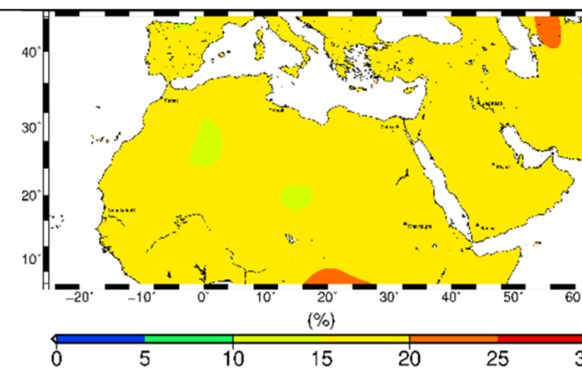

(d)

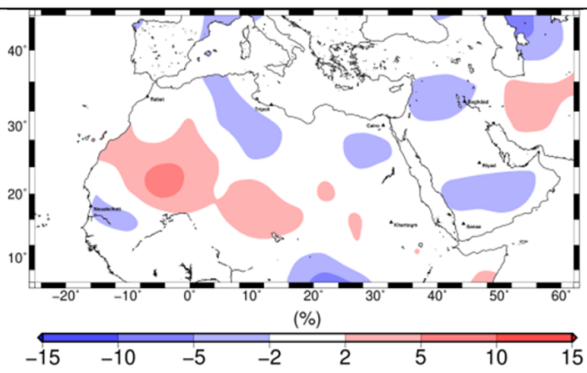

(f)

Fig. 5 Percentage of dry years, as depicted through the drought indices SPI $(\mathbf{a}, \mathbf{b}, \mathbf{e})$ and SPEI $(\mathbf{c}, \mathbf{d}, \mathbf{f})$, simulated by ALADIN-Climate RCM (a, c) and derived from ERA5 reanalysis (b, d) for the historical period (1979-2005) and their respective differences (e, f)

Focusing on MENA region, Zittis (2018) showed significant discrepancies in various aspects of the five gridded observational datasets used, including the monthly time distribution, interannual variability, mean climatology and precipitation extremes. Significant differences have also been identified between several observational and reanalysis products in the case of exceptional extreme rainfall events for the eastern Mediterranean (Zittis et al. 2017). The CMIP5 GCMs and CORDEX RCMs ensembles, evaluated over Africa, overestimated the frequency of extreme precipitation events and produced little high-intensity precipitations compared to observations (Dosio et al. 2015; Gibba et al. 2018). A previous version of ALADIN-Climate (Version 4) as well as the ARPEGE-Climat model (version 4) have been evaluated in the north-west of the region (Morocco) per comparison to meteorological stations data (Driouech et al. 2009; Driouech 2010).
Overall, the model version used in this study shows improved capabilities in reproducing precipitation behaviours across MENA region for both annual total precipitation amounts and high precipitation extremes.

\subsection{Drought}

The model performance in simulating drought across the domain is assessed through the percentage of dry years and the drought indices SPI and SPEI, respectively. For each index, a year is considered as dry if the corresponding index value is below - 1 (McKee et al. 1993; Vicente-Serrano et al. 2010). Our results show that drought occurs in the region with a frequency from 5 to $20 \%$ with SPI and from 10 to $25 \%$ in the case of SPEI. The comparison, across the region, between the numbers of dry years detected by each of the indices in ERA5 data shows that the SPEI tend to 


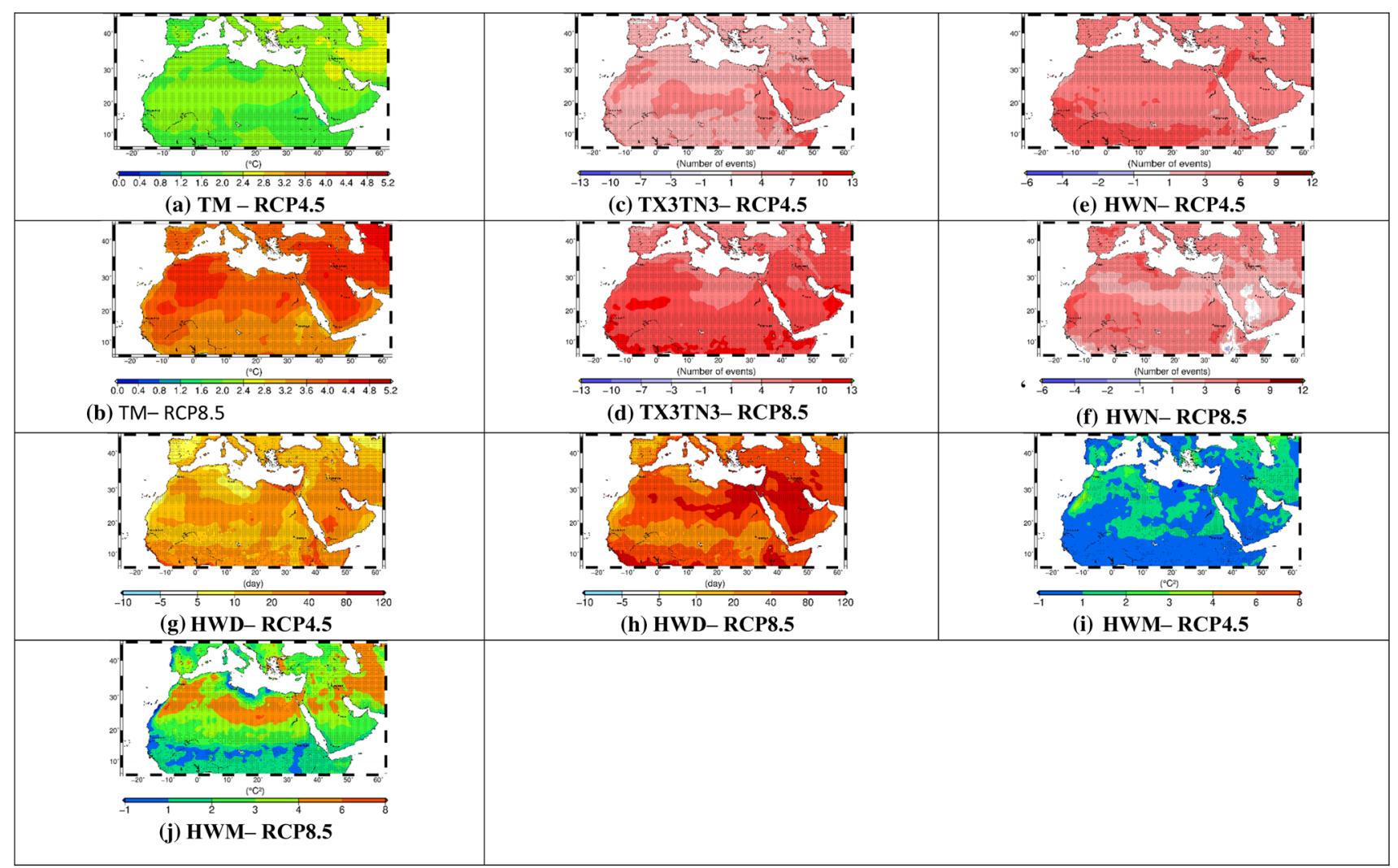

Fig. 6 Future changes of annual mean temperature $(\mathbf{a}, \mathbf{b})\left({ }^{\circ} \mathrm{C}\right)$ ), the number of consecutive hot days and nights (TX3TN3) (c, d) (event) and the number (HWN) (e, f) (event), duration (HWD) (g, h) (days) and magnitude (HWM) $(\mathbf{i}, \mathbf{j})\left({ }^{\circ} \mathrm{C}^{2}\right)$ of heat waves accord-

detect more drought events than the precipitation-based index (Fig. 5). This is due to the taking into account by the SPEI of the effect of temperatures that affects the severity of droughts (Vicente-Serrano et al. 2010). The model reproduces well this behavior furthermore to its ability in simulating satisfactorily drought conditions at the annual scale across the domain, independent of the index used (Fig. 5).

\section{Projected Changes}

Projected changes over the CORDEX-MENA domain are assessed through contrasting ALADIN-climate results for the future period (2071-2100) against the present-day period (1976-2005) under each of the two RCP scenarios (RCP4.5 and RCP8.5).

\subsection{Projected Changes of Mean Temperature and Hot Extremes}

Figure 6 shows the regional scale climate responses to the increase of greenhouse gases, for annual mean temperature ing to the Representative Concentration Pathways scenarios RCP4.5 and RCP8.5. The changes are calculated for period 2071-2100 comparatively to the base period 1976-2005. Stippling indicates where changes are statistically significant at $95 \%$ level

and hot extremes. Results indicate statistically significant changes (at 95\% level) consistent with a generalized warming pattern over the domain, with an increase in mean temperature values around $2{ }^{\circ} \mathrm{C}$ for RCP4.5 (Fig. 6a) and higher for RCP 8.5 (Fig. 6b). The warming is more moderate along the coastal areas compared to inlands. A warming of at least $4{ }^{\circ} \mathrm{C}$ is given with RCP 8.5 in North Africa (Eastern Morocco and most Algeria) and the Arabian Peninsula. The Sahel is projected to warm by around $2{ }^{\circ} \mathrm{C}$ (RCP4.5) to more than $3{ }^{\circ} \mathrm{C}$ warming (RCP8.5). The warming rate is to at least double between the scenario RCP4.5 and RCP8.5, and regional temperature trends over land are estimated to reach $0.2{ }^{\circ} \mathrm{C} /$ decade in RCP4 .5 and $0.49^{\circ} \mathrm{C} /$ decade in RCP8.5 for the period 2020-2100.

The number of consecutive hot days and nights (TX3TN3) is projected to increase by about 2-6 for RCP4.5 and 6-10 for RCP8.5 (Fig. 6b). Compared to the historical period corresponding to one event every 5 years (if not less), these changes correspond to frequencies multiplied by at least 10 . Changes are more homogeneous across the region and exhibit higher increase over the 


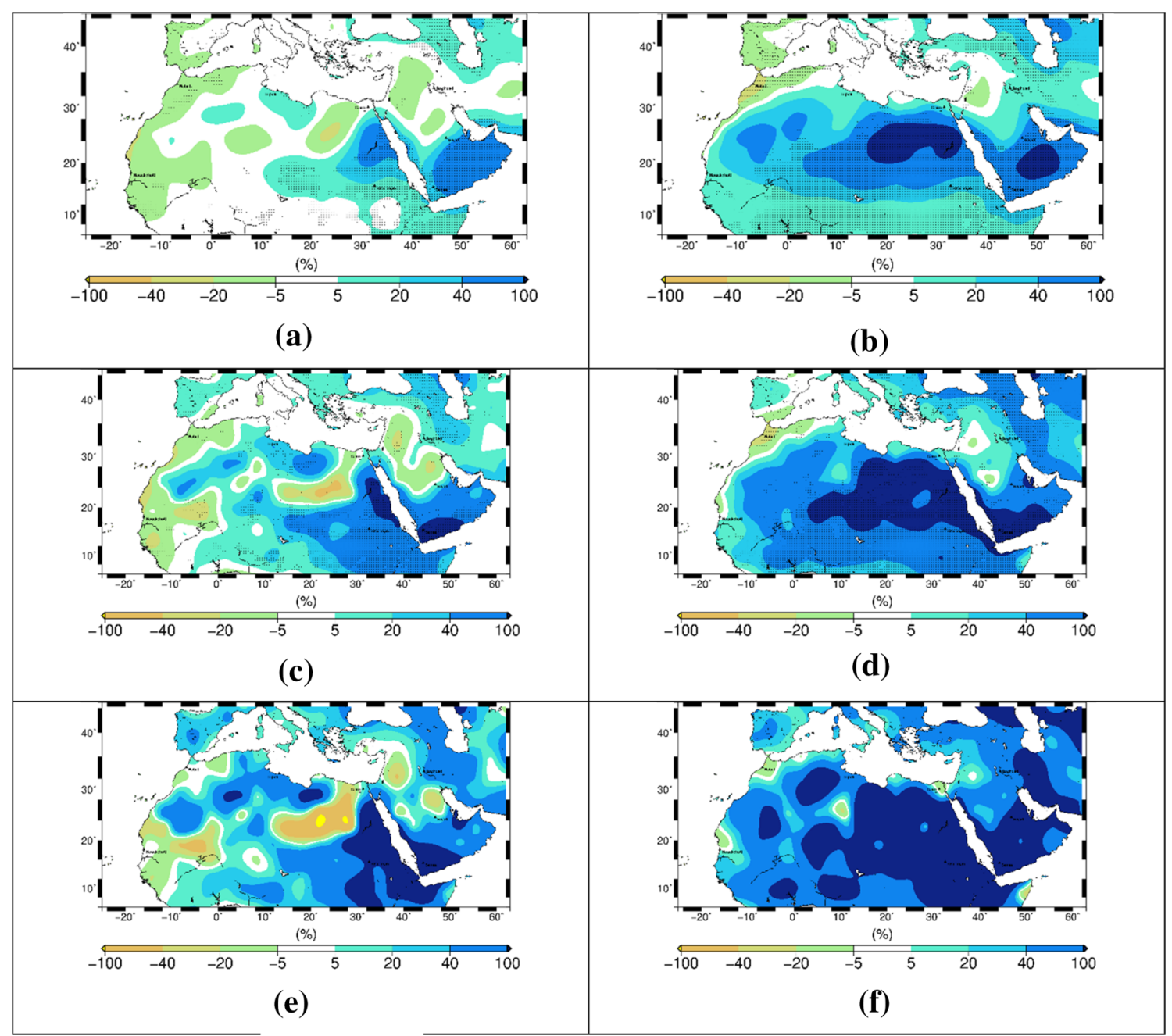

Fig. 7 Future changes (\%) of mean annual total precipitation (a, b) and the total precipitation issued from very wet days (c, d) and extremely wet days $(\mathbf{e}, \mathbf{f})$ according to the RCP4.5 (left) and RCP8.5

Arabian Peninsula and west of Iran ( +4 to +6 days) compared to the remaining parts $(+2$ to +4 days).

There is also an intensification of heat waves in terms of number, duration as well as magnitude, generalized to the whole region but with spatial contrast depending on the index and the scenario (Fig. 6c-e). The number of summer (May-September) heat waves increases for RCP4.5 from 3 to about 10 with the highest values (6-10) in the Sahel. The increase is statistically significant at $95 \%$ level over the whole region for both scenarios but slightly lower with RCP8.5 over the Arabian Peninsula, Egypt and the Sahel.

The changes are statistically significant and more important with RCP8.5 than RCP4.5 for the duration and the magnitude of heat waves particularly over the Arabian Peninsula and North African countries. Some exception is found with the magnitude of heat waves under RCP4.5 where significant changes do not extend to north (right) scenarios. The changes are calculated for the period 20712100 comparatively to the base period 1976-2005. Stippling indicates where changes are statistically significant at $95 \%$ level

of the Arabian Peninsula, Egypt, and part of the Sahel region. The longest heat wave will be more persistent by up to 40 and 80 days for the two scenarios, respectively. The Arabian Peninsula, Egypt and the Horn of Africa reach +100 days with RCP8.5, corresponding to the twothird of the summer period. The magnitude increases with RCP 4.5 by $2{ }^{\circ} \mathrm{C}^{2}-4{ }^{\circ} \mathrm{C}^{2}$ over southern Morocco and less than $2{ }^{\circ} \mathrm{C}^{2}$ elsewhere if not insignificant change. Higher emissions result, however, in higher increase extended to nearly the entire region. The heat wave magnitude will intensify the most over Morocco, Western Algeria, Libya, Egypt and Iran $\left(4{ }^{\circ} \mathrm{C}^{2}-5^{\circ} \mathrm{C}^{2}\right)$. It is worth noting that some studies indicated a potential role of soil moisture-linked feedbacks in the increase of extreme temperatures and heat waves in the mid-latitude heat waves (Douville et al. 2016; Vogel et al. 2017). 


\subsection{Projected Changes of Mean precipitation and High Precipitation Events}

Figure 7 presents the future changes of annual precipitation as issued from ALADIN-Climate. In contrast to the projected changes of temperature, the response to the GHGs emissions are not uniform across the MENA region. A drying is projected with RCP8.5 in the Mediterranean area, over the western part of the domain including Morocco and north-eastern Algeria, consistent with the previous studies (IPCC 2013). The reduction of total precipitation amounts varies from -5 to $-20 \%$ and exceeds $-40 \%$ west of the Atlas Mountains. These changes are significant and consistent with the projected northward shifts of air moisture associated with a stronger North Atlantic Oscillation (NAO) (Waha et al. 2017) and a poleward displacement of the Hadley circulation descending branch (Collins et al. 2013).

On the other hand, precipitation increases in nearly all the remaining parts of the domain. The changes in the Sahara and Arabian Desert correspond to increases exceeding $+40 \%$ or even a doubling of the present-day (historical period) few quantities. The exhibited north-south dipole coincides with increases of about $+10 \%$ to $+40 \%$ over the Sahel and the horn of Africa. With the RCP 4.5, the changes are relatively less intense although they reach a decrease of $5-20 \%$ in North-west Africa and increases of about $40-100 \%$ southern Arabian Peninsula and Egypt. The northward shift of the ITCZ projected by several previous studies including those summarized in IPCC reports (IPCC 2013) is involved in the increase in precipitation over southern parts of the MENA region (Waha et al. 2017). Based on the Mann-Whitney $U$ test, changes under RCP8.5 are statistically significant at 95\% level in most of the region excepting north of the Arabian Desert, south of Algeria, and west of Libya. Significant changes are found for RCP4.5 over the Atlas Mountains, south of the Arabian Peninsula, east of the Sahel and over the Horn of Africa.

The future changes simulated by ALADIN-Climate RCM are in line with projections from previous studies using RCMs or CMIP5 models (Driouech 2010; Collins et al. 2013; Lee and Wang 2014; Gutowski et al. 2016; Waha et al. 2017) including the decrease in total precipitation amounts in the north-west of the region (Morocco) and the increase of precipitation, especially under the intense scenarios, over the Sahara and Southern Arabian Peninsula. Furthermore, using a set of 17 CMIP5 models that includes the CNRM-CM5 (the driving model of ALADIN), Zhao et al. (2014) show also compatible precipitation changes with those issued from ALADIN-Climate. However, it is worth noting that some RCMs project strong decrease in precipitation generalized to all parts of the domain (Ozturk et al. 2018).
Similar behaviors are depicted in the projected changes of very wet days (R95P) with a decrease in precipitation from high events over the band from Morocco and north-west Algeria and more extreme precipitation in the remaining part of the domain (Fig. 7c, d). The highest reductions are given over the northern half of Morocco and reach $-5 \%$ to $-40 \%$ depending on the scenario and location.

The changes in terms of extremely wet days show with RCP8.5 a large predominance of increases across the region, mostly ranging from $+20 \%$ to more than $+80 \%$ (Fig. $7 \mathrm{e}, \mathrm{f}$ ). The areas above $25^{\circ}$ latitude exhibit contrasted changes with either positive or negative signs depending on the location according to RCP4.5. Compatibly with R95P, the very extremely wet days would be less frequent west of the Atlas Mountains with RCP8.5. In general, the future changes noted in mean precipitations across CORDEX-MENA domain should be due to those relative to the high precipitation events at least partially. Although statistically not significant at $95 \%$ level, the results found here for the very high precipitation events are globally compatible with projected changes issued from other models (Cook et al. 2018). The increase of precipitation at the end of twenty-first century in the similar regions is also projected using the latest CMIP6 simulations (Almazroui et al. 2020).

\subsection{Projected Changes of Drought}

According to the SPI, more frequent droughts are expected over North Africa, northern parts of the Arabian Peninsula and parts of the Fertile Crescent (Fig. 8a, b). Extend of the increasing area is, paradoxically, reduced with RCP8.5 and the region concerned by a reduction in the percentage of dry years become larger with the changes mostly statically significant. The later includes the southern half of the Arabian Peninsula, most of the Saharan Desert and the Horn of Africa. Both the positive and negative changes vary from 5 to $20 \%$ excepting over the northern half of Morocco where it reaches $40 \%$ with RCP8.5. Projected increase of drought over Morocco and northern Algeria is statistically significant with RCP8.5

The changes in drought detected using the SPEI (Fig. 8c, d) show more increase in terms of intensity and extent, consistent with the index sensitivity to changes in evaporative demand caused by temperature increase. Temperature rise affects, in fact, the severity of droughts through increased evaporative losses amplifying deficits in soil moisture and runoff, despite fewer precipitation changes. The area above $20^{\circ}$ including North Africa and most of the Middle East would experience statistically significant changes corresponding to an increase of $20-40 \%$ in the percentage of dry years with the highest values exceeding $40 \%$ to a doubling of the present-day ratio. Consistent with the projected increase of mean and extreme 


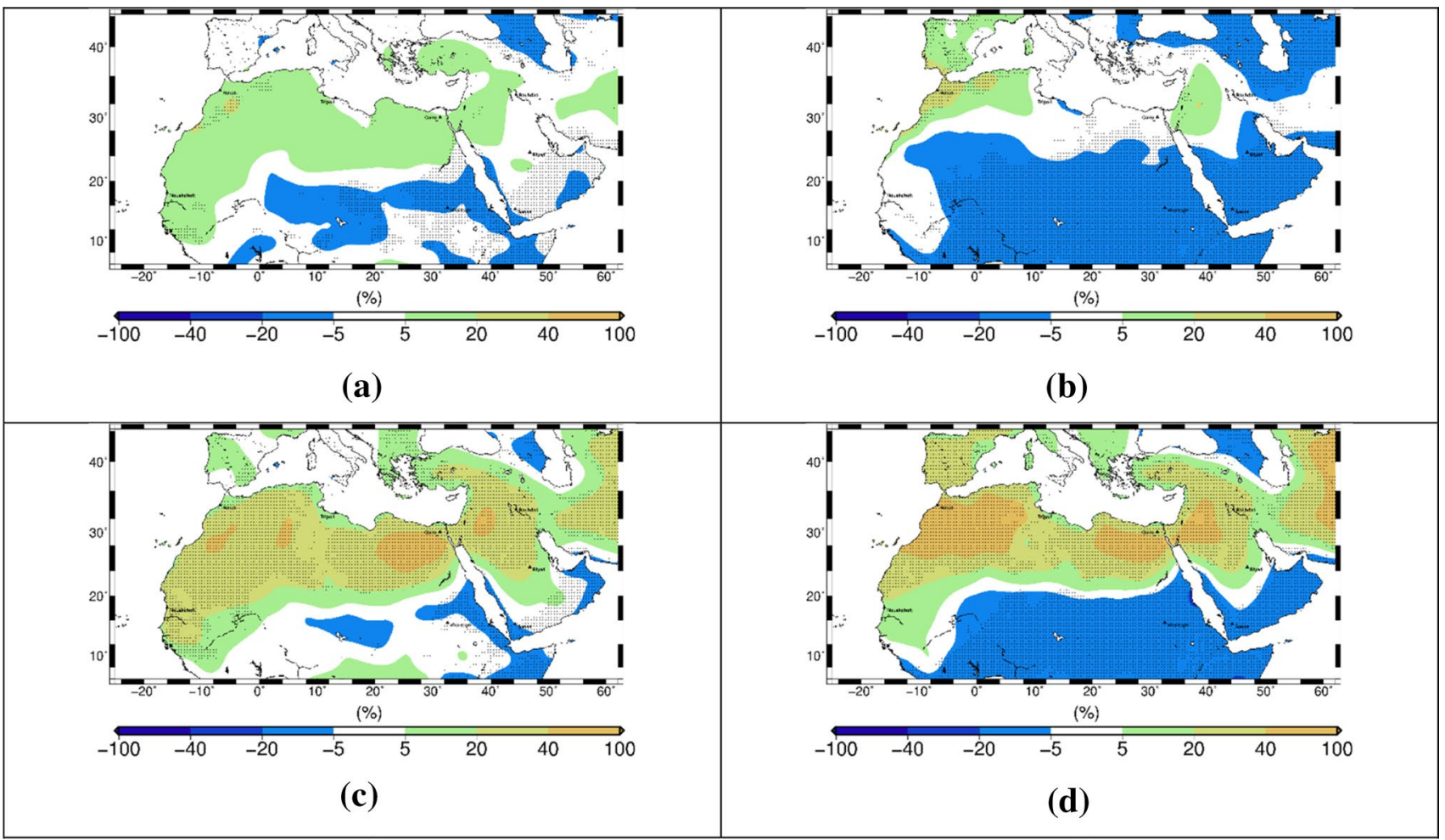

Fig. 8 Future changes of the percentage of dry years as depicted through the drought indices SPI $(\mathbf{a}, \mathbf{b})$ and SPEI $(\mathbf{c}, \mathbf{d})$ according to the Representative Concentration Pathways scenarios RCP4.5 and
RCP8.5. The changes are calculated as the simple difference between future (2071-2100) and reference periods (1976-2005). Stippling indicates where changes are statistically significant at $95 \%$ level precipitation events, less frequent dry years are projected over the remaining southern parts. The significant role of temperature rise has also been found in terms of increased aridity especially in the Mediterranean coastal region due to substantial increase in evapotranspiration (Waha et al. 2017). Land-surface feedbacks tend to increase the drying through contribution to the enhanced warming (Lorenz et al. 2016; Russo et al. 2019).

Our results are in line with various studies that consistently projected the North African countries (notably Morocco, Algeria, and Tunisia), as well as a part of the Middle East area, to become global hot spots for drought by the end of the twentyfirst century (Planton et al. 2008; Collins et al. 2013; Orlowsky and Seneviratne 2013; Sillmann et al. 2013; Prudhomme et al. 2014; Trenberth et al. 2014; Smirnov et al. 2016; Waha et al. 2017, Almazroui et al. 2020). The variation of future drought changes depending on the methodology has also been highlighted (Trenberth et al. 2014) with a larger agreement about the increase of extreme droughts.

\section{Conclusion}

This study reports the first application of the ALADINClimate version 5 Regional Climate Model over the CORDEX-MENA domain, with a focus on assessing the projected climate change responses for mean variables and extreme events under RCP4.5 and RCP8.5 scenarios. The general validation of ALADIN-Climate simulation for the historical period suggests that the model captures reasonably well several climate extreme indices including the excess heat factor related heatwaves and consecutive extreme hot days and nights (TX3TN3). ALADIN-Climate also reproduces the observed mean regional temperature variations and warming trend, though there are cold biases over mountainous regions, also apparent in the CNRM5 driving GCM. The RCM tends also to overestimate mean precipitation over complex terrains and along the belt under the influence of African Monsoon climate. 
Although the multi-model ensemble approach is always preferred to climate change response from a single RCM, which may partly reflect the scientific and numerical choices of this particular model, the analysis of ALADIN-Climate responses over the MENA region provides some important insights. Projected regional warming rate ranges from about $0.2{ }^{\circ} \mathrm{C} / \mathrm{dec}$ ade to $0.5{ }^{\circ} \mathrm{C} / \mathrm{dec}$ ade over land depending on the scenario, and there is an intensification of hot extreme events. Heat waves are projected to intensify in terms of number, duration and magnitude. Precipitation changes are spatially contrasted, with drying over the north-western part. An increase of drought over the northern half of the region is expected, with differences depending on the index and the emission scenario. The effect of warming on the severity of droughts has been detected through the use of SPEI, which is consistent with the finding of previous studies (Cook et al. 2018). Our results are also consistent with several studies that indicate an increase in extreme drought conditions around the Mediterranean, Northern Africa, and the Middle East (Waha et al. 2017; Trenberth et al. 2014).

Due to the wide uncertainty associated with inter-model variability across GCMs, we stress the importance of exploring fully the CORDEX-MENA multi-GCM/multiRCM ensemble to assess the robustness of climate change responses in terms of climate extremes including drought and heat waves over the MENA region. The effects of increasing spatial resolution on the results should also be investigated. The potential impacts of projected changes in human and natural ecosystems need to be assessed in a rigorous way to inform risk reduction decisions.

Acknowledgements The authors are grateful to the Direction de la Météorologie Nationale of Morocco for providing, within their efforts to contribute to the assessment of future changes in MENA region, computing resources to run the model experiments. The authors express thanks to their respective institutions for the support and to Météo-France for providing the initial ALADIN-Climate model configuration. The authors are also grateful to the anonymous reviewers for their helpful comments.

\section{Compliance with Ethical Standards}

Conflict of interest On behalf of all authors, the corresponding author states that there is no conflict of interest.

Open Access This article is licensed under a Creative Commons Attribution 4.0 International License, which permits use, sharing, adaptation, distribution and reproduction in any medium or format, as long as you give appropriate credit to the original author(s) and the source, provide a link to the Creative Commons licence, and indicate if changes were made. The images or other third party material in this article are included in the article's Creative Commons licence, unless indicated otherwise in a credit line to the material. If material is not included in the article's Creative Commons licence and your intended use is not permitted by statutory regulation or exceeds the permitted use, you will need to obtain permission directly from the copyright holder. To view a copy of this licence, visit http://creativecommons.org/licenses/by/4.0/.

\section{References}

Ahmadalipour A, Moradkhani H (2018) Escalating heat-stress mortality risk due to global warming in the Middle East and North Africa (MENA). Env Int 117:215-225

Ahmadalipour A, Moradkhani H, Kumar M (2019) Mortality risk from heat stress expected to hit poorest nations the hardest. Clim Change 152:569-579. https://doi.org/10.1007/s1058 4-018-2348-2

Alexander L, Herold N (2016) ClimPACT2. Indices and software. A document prepared on behalf of The Commission for Climatology $(\mathrm{CCl})$ Expert Team on Sector-Specific Climate Indices (ET-SCI), $46 \mathrm{pp}$

Almazroui M (2019a) Climate extremes over the Arabian Peninsula using RegCM4 for present conditions forced by several CMIP5 models. Atmos 10(11):675. https://doi.org/10.3390/atmos 10110 675

Almazroui M (2019b) Temperature changes over the CORDEX-MENA domain in the 21st century using CMIP5 data downscaled with RegCM4: a focus on the Arabian Peninsula. Adv Meteorol. https ://doi.org/10.1155/2019/5395676

Almazroui M (2020) Summer maximum temperature over the gulf cooperation council states in the twenty-first century: multimodel simulations overview. Arab J Geosci 13:477. https://doi. org/10.1007/s12517-020-05537-x

Almazroui M, Islam MN, Dambul R, Jones PD (2014) Trends of temperature extremes in Saudi Arabia. Int J Climatol 34(3):808-826

Almazroui M, Saeed F, NazrulIslam Md, Alkhalaf AK (2016) Assessing the robustness and uncertainties of projected changes in temperature and precipitation in AR4 Global Climate Models over the Arabian Peninsula. Atmos Res 182:163-175

Almazroui M, Saeed F, Saeed S et al (2020) Projected change in temperature and precipitation over Africa from CMIP6. Earth Syst Environ. https://doi.org/10.1007/s41748-020-00161-x

AlSarmi S, Washington R (2011) Recent observed climate change over the Arabian Peninsula. J Geophys Res Atmos 116:1-15. https:// doi.org/10.1029/2010JD015459

Barlow M, Zaitchik B, Paz S et al (2016) A review of drought in the Middle East and southwest Asia. J Clim 29:8547-8574. https:// doi.org/10.1175/JCLI-D-13-00692.1

Barriopedro D, Fischer EM, Luterbacher J, Trigo RM, García-Herrera R (2011) The hot summer of 2010: redrawing the temperature record map of Europe. Science 332:220-224. https://doi. org/10.1126/science. 1201224

Bucchignani E, Mercogliano P, Rianna G, Panitz HJ (2015) Analysis of ERA-Interim-driven COSMO-CLM simulations over Middle East-North Africa domain at different spatial resolutions. Int J Clim 36:3346-3369. https://doi.org/10.1002/joc.4559

Cattiaux J, Douville H, Peings Y (2013) European temperatures in CMIP5: origins of present-day biases and future uncertainties. Clim Dyn 41:2889-2907. https://doi.org/10.1007/s0038 2-013-1731-y

Colin J, DéQué M, Radu R, Somot S (2010) Sensitivity study of heavy precipitation in Limited Area Model climate simulations: influence of the size of the domain and the use of the spectral nudging technique. Tellus Ser A Dyn Meteorol Oceanogr 62:591-604. https://doi.org/10.1111/j.1600-0870.2010.00467.x

Collins M et al (2013) Climate Change 2013: The Physical Science Basis. Contribution of Working Group I to the Fifth Assessment Report of the Intergovernmental Panel on Climate Change. Climate Change 2013 the Physical Science Basis: Working Group I Contribution to the Fifth Assessment Report of the Intergovernmental Panel on Climate Change. 9781107057:1029-1136

Contractor S, Alexander LV, Donat MG, Herold N (2015) How well do gridded datasets of observed daily precipitation 
compare over Australia? Adv Meteorol 2015:325718. https:// doi.org/10.1155/2015/325718

Cook BI, Mankin JS, Anchukaitis KJ (2018) Climate change and drought: from past to future. Curr Clim Change Rep 4:164-179. https://doi.org/10.1007/s40641-018-0093-2

Dahech S, Beltrando G (2012) Observed temperature evolution in the City of Sfax (Middle Eastern Tunisia) for the period 1950 2007. Clim Change 114:689-706. https://doi.org/10.1007/s1058 4-012-0420-x

Dai A (2011) Characteristics and trends in various forms of the Palmer Drought Severity Index during 1900-2008. J Geophys Res Atmos 116:D12115. https://doi.org/10.1029/2010JD015541

Déqué M (2010) Regional climate simulation with a mosaic of RCMs. Meteorol Zeit 19:259-266. https://doi. org/10.1127/0941-2948/2010/0455

Déqué M, Somot S (2008) Analysis of heavy precipitation for France using high resolution ALADIN RCM simulations. Q J Hung Meteorol Serv 112(3-4):179-190

Déqué M, Calmanti S, Christensen OB et al (2017) A multi-model climate response over tropical Africa at $+2{ }^{\circ} \mathrm{C}$. Clim Serv. https ://doi.org/10.1016/j.cliser.2016.06.002

Diedhiou A, Janicot S, Viltard A, de Felice P (1998) Evidence of two regimes of easterly waves over West Africa and the tropical Atlantic. Geophys Res Lett 25(15):2805-2808. https://doi. org/10.1029/98GL02152

Dike VN et al (2015) Modelling present and future African climate using CMIP5 scenarios in HadGEM2-ES. Int J Climatol 35:1784-1799. https://doi.org/10.1002/joc.4084

Donat MG et al (2014) Changes in extreme temperature and precipitation in the Arab region: long-term trends and variability related to ENSO and NAO. Int J Climatol 34:581-592. https://doi. org/10.1002/joc. 3707

Dosio A, Panitz H-J, Schubert-Frisius M, Lüthi D (2015) Dynamical downscaling of CMIP5 global circulation models over CORDEX-Africa with COSMO-CLM: evaluation over the present climate and analysis of the added value. Clim Dyn 44:2637-2661. https://doi.org/10.1007/s00382-014-2262-x

Douville H, Colin J, Krug E, Cattiaux J, Thao S (2016) Midlatitude daily summer temperatures reshaped by soil moisture under climate change. Geophys Res Lett 43:812-818. https://doi. org/10.1002/2015GL066222

Driouech F (2010) Distribution des précipitations hivernales sur le Maroc dans le cadre d'un changement climatique: descente d'échelle et incertitudes, pp 1-164

Driouech F, Déqué M, Mokssit A (2009) Numerical simulation of the probability distribution function of precipitation over Morocco. Clim Dyn 32:1055-1063. https://doi.org/10.1007/s0038 2-008-0430-6

Driouech F, Déqué M, Sánchez-Gómez E (2010) Weather regimesMoroccan precipitation link in a regional climate change simulation. Glob Planet Change 72(1-2):1-10. https://doi. org/10.1016/j.gloplacha.2010.03.004

Driouech F, Ben Rached S, Al Hairech T (2013) Climate variability and change in North African Countries, Chap 9. In: Sivakumar MVK, Lal R, Selvaraju R, Hamdan I (eds) Climate change and food security in West Asia and North Africa. Springer, Dordrecht Heidelberg New York London. https://doi. org/10.1007/978-94-007-6751-5

El Kenawy AM, McCabe MF (2016) Future projections of synoptic weather types over the Arabian Peninsula during the twenty-first century using an ensemble of CMIP5 models. Theor Appl Clim. https://doi.org/10.1007/s00704-016-1874-y

Fantini A et al (2018) Assessment of multiple daily precipitation statistics in ERA-Interim driven Med-CORDEX and EURO-CORDEX experiments against high resolution observations. Clim Dyn 130:173-189. https://doi.org/10.1007/s00382-016-3453-4
Farda A et al (2010) Model ALADIN as regional climate model for Central and Eastern Europe. Stud Geophys Geod 54:313-332. https://doi.org/10.1007/s11200-010-0017-7

Field C, Barros V, Stocker T, Qin D, Dokken D et al (2012) Managing the risks of extreme events and disasters to advance climate change adaptation: special report of the intergovernmental panel on climate change. Cambridge Univ. Press, Cambridge

Filahi S, Tanarhte M, Mouhir L, El Morhit M, Tramblay Y (2015) Trends in indices of daily temperature and precipitations extremes in Morocco. Theor Appl Climatol 124(3-4):959-972. https://doi.org/10.1007/s00704-015-1472-4

Flohr P, Fleitmann D, Zorita E et al (2017) Late Holocene droughts in the Fertile Crescent recorded in a speleothem from northern Iraq. Geophys Res Lett 44:1528-1536. https://doi. org/10.1002/2016GL071786

Gebremeskel G, Tang Q, Sun S et al (2019) Droughts in East Africa: causes, impacts and resilience. Earth Sci Rev 193:146-161

Gibba P, Sylla MB, Okogbue EC, Gaye AT, Nikiema M et al (2018) State-of-the-art climate modeling of extreme precipitation over Africa: analysis of CORDEX added-value over CMIP5. Theor Appl Climatol 137:1041-1057. https://doi.org/10.1007/s0070 4-018-2650-y

Giorgi F, Gutowski WJ (2015) Regional dynamical downscaling and the CORDEX initiative. Annu Rev Environ Resour 40:467490. https://doi.org/10.1146/annurev-environ-102014-021217

Giorgi F, Lionello P (2008) Climate change projections for the Mediterranean region. Glob Planet Change 63:90-104. https://doi. org/10.1016/j.gloplacha.2007.09.005

Giorgi F, Coppola E, Raffaele F et al (2014) Changes in extremes and hydroclimatic regimes in the CREMA ensemble projections. Clim Change 125:39-51. https://doi.org/10.1007/s1058 4-014-1117-024

Gutowski WJ et al (2016) WCRP COordinated Regional Downscaling EXperiment (CORDEX): a diagnostic MIP for CMIP6. Geosci Model Dev 9:4087-4095. https://doi.org/10.5194/ gmd-9-4087-2016

Hansen BU et al (2008) Present-day climate at Zackenberg. Adv Ecol Res 40:111-149. https://doi.org/10.1016/S0065 -2504(07)00006-2

Hernández-Díaz L et al (2013) Climate simulation 5 over CORDEX Africa domain using the fifth-generation Canadian Regional Climate Model (CRCM5). Clim Dyn 40:1415-1433. https:// doi.org/10.1007/s00382-012-1387-z

Herrmann M, Somot S, Calmanti S, Dubois C, Sevault F (2011) Representation of spatial and temporal variability of daily wind speed and of intense wind events over the Mediterranean Sea using dynamical downscaling: impact of the regional climate model configuration. Nat Hazards Earth Syst Sci 11:19832001. https://doi.org/10.5194/nhess-11-1983-2011

Hersbach $\mathrm{H}$ et al. (2018) Operational global reanalysis: progress, future directions and synergies with NWP, ERA Report Series. https://doi.org/10.21957/tkic6g3wm

Hersbach H, Dee D (2016) ERA5 reanalysis is in production, ECMWF Newsletter 147, ECMWF

Hersbach H et al (2019) The ERA5 Global Atmospheric Reanalysis at ECMWF as a comprehensive dataset for climate data homogenization, climate variability, trends and extremes. Geophys Res Abstr 21:1-1

Huffman GJ et al (2007) The TRMM multisatellite precipitation analysis (TMPA): quasi-global, multiyear, combined-sensor precipitation estimates at fine scales. J Hydrometeorol 8:38-55. https://doi.org/10.1175/JHM560.1

Huffman GJ, Adler RF, Bolvin DT, Gu G (2009) Improving the global precipitation record: GPCP Version 2.1. Geophys Res Lett 36:L17808. https://doi.org/10.1029/2009GL040000 
IPCC (2013) Climate Change 2013: The Physical Science Basis Contribution of Working Group I to the 16 Fifth Assessment Report of the Intergovernmental Panel on Climate Change. Cambridge University Press, Cambridge

IPCC (2018) Summary for policymakers. In: Masson-Delmotte V, Zhai P, Pörtner H-O, Roberts D, Skea J, Shukla PR, Pirani A, Moufouma-Okia W, Péan C, Pidcock R, Connors S, Matthews JBR, Chen Y, Zhou X, Gomis MI, Lonnoy E, Maycock $\mathrm{T}$, Tignor M, Waterfield T (eds) Global warming of $1.5^{\circ} \mathrm{C}$. An IPCC special report on the impacts of global warming of $1.5^{\circ} \mathrm{C}$ above pre-industrial levels and related global greenhouse gas emission pathways, in the context of strengthening the global response to the threat of climate change, sustainable development, and efforts to eradicate poverty. World Meteorological Organization, Geneva, Switzerland, $32 \mathrm{p}$

Islam MN, Almazroui M, Dambul R, Jones PD, Alamoudi AO (2015) Long-term changes in seasonal temperature extremes over Saudi Arabia during 1981-2010. Int J Climatol 35(7):1579-1592

Jacob D, Petersen J, Eggert B et al (2014) EURO-CORDEX: new high-resolution climate change projections for European impact research. Reg Environ Change 14:563-578. https://doi. org/10.1007/s10113-013-0499-2

James R, Washington R (2013) Changes in African temperature and precipitation associated with degrees of global warming. Clim Change 117:859-872. https://doi.org/10.1007/s1058 4-012-0581-7

Kelley CP, Mohtadi S, Cane MA, Seager R, Kushnir Y (2015) Climate change in the fertile crescent and implications of the recent Syrian drought. Proc Natl Acad Sci 112(11):3241-3246. https://doi. org/10.1073/pnas.1421533112

Laprise R, Hernández-Díaz L, Tete K et al (2013) Climate projections over CORDEX Africa domain using the fifth-generation Canadian Regional Climate Model (CRCM5). Clim Dyn 41:32193246. https://doi.org/10.1007/s00382-012-1651-2

Flato et al (2013) Evaluation of Climate Models. In: Intergovernmental Panel on Climate Change (ed) Climate Change 2013-The Physical Science Basis. Cambridge University Press, Cambridge, pp 741-866

Lee JY, Wang B (2014) Future change of global monsoon in the CMIP5. Clim Dyn 42:101-119. https://doi.org/10.1007/s0038 2-012-1564-0

Lelieveld J, Proestos Y, Hadjinicolaou P et al (2016) Strongly increasing heat extremes in the Middle East and North Africa (MENA) in the 21st century. Clim Change 137:245-260. https://doi. org/10.1007/s10584-016-1665-6

Lennard CJ, Nikulin G, Dosio A, Moufouma-Okia W (2018) On the need for regional climate information over Africa under varying levels of global warming. Environ Res Lett 13(6):060401. https ://doi.org/10.1088/1748-9326/aab2b4

Linares JC, Camarero JJ (2012) From pattern to process: linking intrinsic water-use efficiency to drought-induced forest decline. Glob Chang Biol 18:1000-1015. https://doi.org/10.11 $11 / \mathrm{j} .1365-2486.2011 .02566 . x$

Llopart M et al (2014) Climate change impact on precipitation for the Amazon and La Plata basins. Clim Change 125:111-125. https ://doi.org/10.1007/s10584-014-1140-1

Lorenz R et al (2016) Influence of land-atmosphere feedbacks on temperature and precipitation extremes in the GLACE-CMIP5 ensemble. J Geophys Res Atmos 121:607-623. https://doi. org/10.1002/2015JD024053

Mallet $\mathrm{M}$ et al (2019) Simulation of the transport, vertical distribution, optical properties and radiative impact of smoke aerosols with the ALADIN regional climate model during the ORACLES-2016 and LASIC experiments. Atmos Chem Phys 19(7):4963-4990
Mansouri B (2004) Impact of drought and fiscal policy on private consumption, private investment and economic growth in Morocco: an empirical analysis. Pros Arab Econ Coop 1-20

Mba WP et al (2018) Consequences of $1.5^{\circ} \mathrm{C}$ and $2{ }^{\circ} \mathrm{C}$ global warming levels for temperature and precipitation changes over Central Africa. Environ Res Lett 13(5):055011

McKee TB, Doesken NJ, Kleist J (1993) The relationship of drought frequency and duration to time scales. J Surg Oncol 105:17-22

Meehl GA, Tebaldi C (2004) More intense, more frequent, and longer lasting heat waves in the 21st century. Science 305:994-997. https://doi.org/10.1126/science.1098704

Merlone A et al (2019) Temperature extreme records: World Meteorological Organization metrological and meteorological evaluation of the $54.0^{\circ} \mathrm{C}$ observations in Mitribah, Kuwait and Turbat, Pakistan in 2016/2017. Int J Climatol 39:5154-5169. https://doi. org/10.1002/joc.6132

Mwangi E, Wetterhall F, Dutra E et al (2014) Forecasting droughts in East Africa. Hydrol Earth Syst Sci 18:611-620. https://doi. org/10.5194/hess-18-611-2014

Nabat P, Somot S, Mallet M, Sanchez-Lorenzo A, Wild M (2014) Contribution of anthropogenic sulfate aerosols to the changing Euro-Mediterranean climate since 1980. Geophys Res Lett 41:5605-5611. https://doi.org/10.1002/2014GL060798

Nasrallah HA, Nieplova E, Ramadan E (2004) Warm season extreme temperature events in Kuwait. J Arid Environ 56:357-371. https ://doi.org/10.1016/S0140-1963(03)00007-7

Orlowsky B, Seneviratne SI (2013) Elusive drought: Uncertainty in observed trends and short-and long-term CMIP5 projections. Hydrol Earth Syst Sci 17:1765-1781. https://doi.org/10.5194/ hess-17-1765-2013

Ozturk T, Turp MT, Türkeş M, Kurnaz ML (2018) Future projections of temperature and precipitation climatology for CORDEXMENA domain using RegCM4.4. Atmos Res 206:87-107. https ://doi.org/10.1016/j.atmosres.2018.02.009

Perkins SE, Alexander LV (2013) On the measurement of heat waves. J Clim 26:4500-4517. https://doi.org/10.1175/JCLI-D-12-00383.1

Peterson TC (2005) Climate change indices. WMO Bull 54:83-86

Planton S, Déqué M, Chauvin F, Terray L (2008) Expected impacts of climate change on extreme climate events. Comp Ren Geosci 340:564-574. https://doi.org/10.1016/j.crte.2008.07.009

Prein AF, Gobiet A (2017) Impacts of uncertainties in European gridded precipitation observations on regional climate analysis. Int $\mathbf{J}$ Climatol 37(1):305-327. https://doi.org/10.1002/joc.4706

Prudhomme C et al (2014) Hydrological droughts in the 21st century, hotspots and uncertainties from a global multimodel ensemble experiment. Proc Natl Acad Sci USA 111:3262-3267. https:// doi.org/10.1073/pnas.1222473110

Radu R, Déqué M, Somot S (2008) Spectral nudging in a spectral regional climate model. Tellus Ser A Dyn Meteorol Oceanogr 60:898-910. https://doi.org/10.1111/j.1600-0870.2008.00341.x

Roudier P, Andersson JCM, Donnelly C et al (2015) Projections of future floods and hydrological droughts in Europe under $\mathrm{a}+2^{\circ} \mathrm{C}$ global warming. Clim Change 135:341-355

Rowell DP, Booth BBB, Nicholson SE, Good P (2015) Reconciling past and future rainfall trends over East Africa. J Clim 28(24):9768-9788. https://doi.org/10.1175/JCLI-D-15-0140.1

Rummukainen M (2010) State-of-the-art with regional. Clim Change 1:82-96. https://doi.org/10.1002/wcc.008

Russo A, Gouveia CM, Dutra E, Soares PMM, Trigo RM (2019) The synergy between drought and extremely hot summers in the Mediterranean. Environ Res Lett 14:014011

Ruti PM et al (2016) Med-CORDEX initiative for Mediterranean climate studies. Bull Am Meteorol Soc 97(7):1187-1208. https:// doi.org/10.1175/BAMS-D-14-00176.1

Salas-Mélia D et al (2005) Description and validation of the CNRMCM3 global coupled model. Note de Centre du GMGEC 103:36 
Shongwe ME, van Oldenborgh GJ, van den Hurk B, van Aalst M (2011) Projected changes in mean and extreme precipitation in Africa under global warming. Part II: East Africa. J Clim 24(14):3718-3733. https://doi.org/10.1175/2010JCLI2883.1

Sillmann J, Kharin VV, Zwiers FW, Zhang X, Bronaugh D (2013) Climate extremes indices in the CMIP5 multimodel ensemble: Part 2. Future climate projections. J Geophys Res Atmos 118:24732493. https://doi.org/10.1002/jgrd.50188

Smirnov $\mathrm{O}$ et al (2016) The relative importance of climate change and population growth for exposure to future extreme droughts. Clim Change 138:41-53. https://doi.org/10.1007/s10584-016-1716-z

Somot $S$ et al (2018) Editorial for the Med-CORDEX special issue. Clim Dyn 51:771-777. https://doi.org/10.1007/s0038 2-018-4325-x

Sowers J, Vengosh A, Weinthal E (2011) Climate change, water resources, and the politics of adaptation in the Middle East and North Africa. Clim Change 104:599-627. https://doi. org/10.1007/s10584-010-9835-4

Spiridonov V, Valcheva R (2019) A new index for climate change evaluation - an example with the ALADIN and RegCM regional models for the Balkans and the Apennines. IDOJARAS 123(4):551-576

Syed FS, Latif M, Al-Maashi A, Ghulam A (2019) Regional climate model RCA4 simulations of temperature and precipitation over the Arabian Peninsula: sensitivity to CORDEX domain and lateral boundary conditions. Clim Dyn 53:7045-7064. https://doi. org/10.1007/s00382-019-04974-z

Sylla MB, Giorgi F, Coppola E, Mariotti L (2013) Uncertainties in daily rainfall over Africa: assessment of gridded observation products and evaluation of a regional climate model simulation. Int J Climatol 33:1805-1817. https://doi.org/10.1002/joc.3551

Tanarhte M, Hadjinicolaou P, Lelieveld J (2012) Intercomparison of temperature and precipitation data sets based on observations in the Mediterranean and the Middle East. J Geophys Res 117(D12):D12102+. https://doi.org/10.1029/2011jd017293

Torma C, Giorgi F, Coppola E (2015) Added value of regional climate modeling over areas characterized by complex terrain-precipitation over the Alps. J Geophys Res 120:3957-3972. https://doi. org/10.1002/2014JD022781

Tramblay Y, Ruelland D, Somot S, Bouaicha R, Servat E (2013) Highresolution Med-CORDEX regional climate model simulations for hydrological impact studies: A first evaluation of the ALADINClimate model in Morocco. Hydrol Earth Syst Sci 17:37213739. https://doi.org/10.5194/hess-17-3721-2013

Trenberth KE et al (2014) Global warming and changes in drought. Nat Clim Chang 4:17-22. https://doi.org/10.1038/nclimate2067

United Nations Economic and Social Commission for Western Asia (ESCWA) et al. (2017) Arab Climate Change Assessment Report-Main Report. E/ESCWA/SDPD/2017/RICCAR/Report pp.
Vaittinada AP et al (2016) Intercomparison of statistical and dynamical downscaling models under the EURO- and MED-CORDEX initiative framework: present climate evaluations. Clim Dyn 46:1301-1329. https://doi.org/10.1007/s00382-015-2647-5

Vicente-Serrano SM, Beguería S, López-Moreno JI (2010) A multiscalar drought index sensitive to global warming: the standardized precipitation evapotranspiration index. J Clim 23(7):1696-1718

Vicente-Serrano SM et al (2014) Evidence of increasing drought severity caused by temperature rise in southern Europe. Environ Res Lett 9:044001

Vogel MM et al (2017) Regional amplification of projected changes in extreme temperatures strongly controlled by soil moisturetemperature feedbacks. Geophy Res Lett 44:1511-1519. https:// doi.org/10.1002/2016GL071235

Voldoire A et al (2013) The CNRM-CM5.1 global climate model: description and basic evaluation. Clim Dyn 40:2091-2121. https ://doi.org/10.1007/s00382-011-1259-y

Waha K et al (2017) Climate change impacts in the Middle East and Northern Africa (MENA) region and their implications for vulnerable population groups. Reg Environ Change 17:1623-1638. https://doi.org/10.1007/s10113-017-1144-2

World Meteorological Organisation (2012) Standardized Precipitation Index, User Guide. WMO-No. 1090

Zhang X, Aguilar E, Sensoy S et al (2005) Trends in Middle East climate extreme indices from 1950 to 2003. J Geophys Res Atmos 110:1-12. https://doi.org/10.1029/2005JD006181

Zhang X, Alexander L, Hegerl GC et al (2011) Indices for monitoring changes in extremes based on daily temperature and precipitation data. Wiley Interdiscip Rev Clim Change 2:851-870. https://doi. org/10.1002/wcc. 147

Zhao T, Chen L, Ma Z (2014) Simulation of historical and projected climate change in arid and semiarid areas by CMIP5 models. Chin Sci Bull 59(4):412-429. https://doi.org/10.1007/s1143 4-013-0003-x

Zittis G (2018) Observed rainfall trends and precipitation uncertainty in the vicinity of the Mediterranean, Middle East and North Africa. Theor Appl Climatol 134:1207-1230. https://doi.org/10.1007/ s00704-017-2333-0

Zittis G, Hadjinicolaou P, Lelieveld J (2014) Comparison of WRF model physics parameterizations over the MENA-CORDEX domain. Am J Clim Change 03:490-511. https://doi.org/10.4236/ ajcc.2014.35042

Zittis G, Bruggeman A, Camera C, Hadjinicolaou P, Lelieveld J (2017) The added value of convection permitting simulations of extreme precipitation events over the eastern Mediterranean. Atmos Res 191:20-33. https://doi.org/10.1016/j.atmosres.2017.03.002

Zou L, Zhou T (2016) A regional ocean-atmosphere coupled model developed for CORDEX East Asia: assessment of Asian summer monsoon simulation. Clim Dyn 47:3627-3640. https://doi. org/10.1007/s00382-016-3032-8 